\title{
QUANTITATIVE STUDIES ON ENZYME SYSTEM OF HETEROLACTIC FERMENTATION
}

\author{
III. INTRACELLULAR ACTIVITY OF \\ 2-KETO-6-PHOSPHOGLUCONATE DECARBOXYLASE \\ DURING GLUCOSE FERMENTATION
}

\author{
SHIGETAKA YASHIMA $^{1}$ AND KAKUO KITAHARA ${ }^{2}$ \\ The Institute of Applied Microbiology, University of Tokyo, Tokyo
}

(Received February 10, 1969)

\begin{abstract}
The activity of 2-keto-6-phosphogluconate decarboxylase in the sonicate of washed cells of Leuconostoc mesenteroides B07 was estimated. The value calculated for intracellular activity of the decarboxylase showed good agreement with that for heterolactic fermenting activity of the washed cells.

It was concluded that oxidative decarboxylation of 6-phosphogluconate in the organism depends quantitatively on the decarboxylase.
\end{abstract}

In the previous work, studies were made on the intracellular conditions of glucose-metabolizing cells of Leuconostoc mesenteroides B07 (1). From these results and the basic properties of glucose-6-phosphate dehydrogenase and lactate dehydrogenase, quantitative estimation of the intracellular activities of these dehydrogenases in the washed cells were made $(2,3)$. These results showed that heterolactic fermentation in this organism depended quantitatively on both dehydrogenases.

Quantitative studies were also made on homolactic fermentation system in Lactobacillus plantarum No. 11 (4-9).

Recently, it was estimated that the oxidative decarboxylation of 6-phosphogluconate in Leuconostoc mesenteroides B07 may be due to two enzymes, 6-phosphogluconate dehydrogenase (not decarboxylating) [EC 1.1.1.43] and a new enzyme 2-keto-6-phosphogluconate decarboxylase (10-12), and it was also confirmed that intracellular activity of this dehydrogenase is nearly equal to that of heterolactic fermentation in the washed cells, showing a significant participation of the dehydrogenase in metabolic pathway of the fermentation in this strain (13).

In the present work, an attempt was made to determine the intracellular

1 Present address: Department of Microbial Technology, Faculty of Agriculture, Hokkaido University, Sapporo, Hokkaido 060.

2 Present address: Tokyo University of Agriculture, Setagaya-ku, Tokyo 156. 
activity of 2-keto-6-phosphogluconate decarboxylase during glucose fermentation, especially with respect to its relation to the rate of the fermentation in the organism.

\section{MATERIALS AND METHODS}

Materials. Leuconostoc mesenteroides B07 used throughout this work was isolated and identified in this laboratory. The strain is a typical heterolactic fermenting coccus and was maintained as a stab culture in malt extractbouillon-agar containing $\mathrm{CaCO}_{3}$. The methods for cultivation and preparation of washed cells have been described (1). Aerobacter aerogenes IAM 1183 for preparation of purified 2-ketogluconokinase was obtained from Dr. H. Iizuka of this Institute.

Authentic 2-keto-6-phosphogluconate (2K-6PGA) was prepared from 2keto-D-gluconate by ATP and 2-ketogluconokinase system according to the method of FRAMPTON and WoOD (14). Purified 6-phosphogluconate (6PGA) dehydrogenase (not decarboxylating) was prepared from Leuconostoc mesenteroides $\mathrm{B} 07$ by the method reported previously (10). 2-Keto-D-gluconate was obtained from the Takeda Chemical Industries Ltd. $\mathrm{NADH}_{2}$ and ATP were purchased from the Nutritional Biochemical Corp.

Methods. Activities of 2K-6PGA decarboxylase were calculated from the initial linear rate of $\mathrm{CO}_{2}$ evolution in Warburg vessels. The reaction mixture contained, in $2 \mathrm{ml}, 10 \mu$ moles of $2 \mathrm{~K}-6 \mathrm{PGA}, 50 \mu$ moles of acetate buffer $(\mathrm{pH} 5.0$ ), and the enzyme. At the end of the reaction, $0.2 \mathrm{ml}$ of $0.5 \mathrm{~N}$ $\mathrm{H}_{2} \mathrm{SO}_{4}$ was added from a side arm of the vessel. In this standard assay condition $\left(30^{\circ}\right)$, spontaneous decarboxylation of $2 \mathrm{~K}-6 \mathrm{PGA}$ could not be detected. One unit of enzyme activity was defined as the amount of enzyme causing decarboxylation of one $\mu$ mole of $2 \mathrm{~K}-6 \mathrm{PGA} / \mathrm{hr}$.

Lactate was determined by the method of BARKER and SUMMERSON (15).

\section{RESULTS}

Intracellular concentration of 2K-6PGA in glucose-metabolizing washed cells

To estimate the intracellular activity of $2 \mathrm{~K}-6 \mathrm{PGA}$ decarboxylase, it was necessary to determine the intracellular concentration of $2 \mathrm{~K}-6 \mathrm{PGA}$ in glucosemetabolizing washed cells of the organism.

Leuconostoc mesenteroides B07 was cultivated, and the washed cells were prepared as previously reported (1). An amount of $0.8 \mathrm{~g}$ (dry weight) of the washed cells thus obtained was suspended in $40 \mathrm{ml}$ of phosphate buffer $\left(30^{\circ}\right.$, $\mathrm{pH}$ 6.6) containing 2.0 mmoles of glucose, $120 \mu$ moles of $\mathrm{MgCl}_{2}$, and $1.2 \mu \mathrm{mole}$ of $\mathrm{MnCl}_{2}$. After $10 \mathrm{~min}$ of incubation at $30^{\circ}$, the suspension was poured into $360 \mathrm{ml}$ of boiling water to stop the fermentation instantly. After being maintained at $100^{\circ}$ for $2 \mathrm{~min}$, the suspension was allowed to cool to room temperature, and then centrifuged at $20,000 \times g$ for $15 \mathrm{~min}$ to remove cell debris. 
The clear supernatant thus obtained was concentrated to $20 \mathrm{ml}$ in vacuo, adjusted to $\mathrm{pH} 7.5$ with $1 \mathrm{M} \mathrm{K}_{2} \mathrm{HPO}_{4}$, and then water was added to bring the total volume to $30 \mathrm{ml}$.

From the result of lactate determination using the concentrated extract, the washed cells were found to form $6.1 \mu$ moles of lactate/mg of dry cells/ $\mathrm{hr}$, and this is a normal rate of heterolactic fermentation for this strain as reported previously $(1,13)$.

In preliminary studies on the spectrophotometric determination of $2 \mathrm{~K}$ 6PGA with purified 6PGA dehydrogenase (not decarboxylating), it was found that the initial rate of $\mathrm{NADH}_{2}$ oxidation is approximately proportional to $2 \mathrm{~K}$ 6PGA concentration $(0.1-0.5 \mu$ mole $)$ under the following assay conditions.

The reaction mixture contained $1.5 \mathrm{ml}$ of the extract, $0.5 \mu$ mole of $\mathrm{NADH}_{2}$, $150 \mu \mathrm{g}$ of purified $6 \mathrm{PGA}$ dehydrogenase, and water to bring the total volume to $3.0 \mathrm{ml}$. The reaction was carried out at $30^{\circ}$, and the initial linear rate of decrease in optical density at $340 \mathrm{~m} \mu$ was measured against a blank containing water instead of the dehydrogenase. The 2K-6PGA content of the extract was obtained by reading off from the standard curve the concentration of $2 \mathrm{~K}-6 \mathrm{PGA}$ corresponding to the initial reaction velocity. Starting from the extraction procedure, recovery of the added 2K-6PGA was found to be $93 \%$.

By this method, the concentration of $2 \mathrm{~K}-6 \mathrm{PGA}$ was determined to be $0.13 \mu \mathrm{mole} / \mathrm{ml}$ of the extract. As the volume of cytoplasmic solution corresponding to $1 \mathrm{~g}$ of dry cells of this strain was previously found to be 1.38 $\mathrm{cm}^{3}(1)$, the intracellular concentration of 2K-6PGA was calculated to be 3.5 $\times 10^{-3} \mathrm{M}$. This result was also confirmed when the extraction was performed for $5 \mathrm{~min}$ at $100^{\circ}$, indicating that the decomposition of $2 \mathrm{~K}-6 \mathrm{PGA}$ did not occur during the extraction, and that the intracellular 2K-6PGA was thoroughly extracted by 2 min of extraction. The extracellular 2K-6PGA could not be detected under various assay conditions.

\section{Intracellular activity of $2 K-6 P G A$ decarboxylase}

Fig. 1 shows the relationship between the appearance of the decarboxylase activity and that of optical density at $280 \mathrm{~m} \mu$ in the cell-free supernatant during sonic oscillation. This graph indicates that cell-free protein released from the cells, as estimated by the increase in optical density at $280 \mathrm{~m} \mu$, attained a maximum after a 40-min exposure to sonic oscillation, whereas the enzyme activity began to fall after a 26-min exposure. Though the inactivation was found to occur in the late period of the sonication, the inactivation rate seemed to be less than $5 \%$ for $5 \mathrm{~min}$. Therefore, the activity in the sonicate, corrected for the inactivation during the sonication, was roughly estimated from the following equation, assuming that the enzyme is uniformly distributed in the cytoplasm:

$$
\text { Total activity }=\frac{\text { activity after } 5^{\prime} \text { sonic. } \times \mathrm{OD}_{280} \text { after } 40^{\prime} \text { sonic. }}{\mathrm{OD}_{280} \text { after } 5^{\prime} \text { sonic. }}
$$




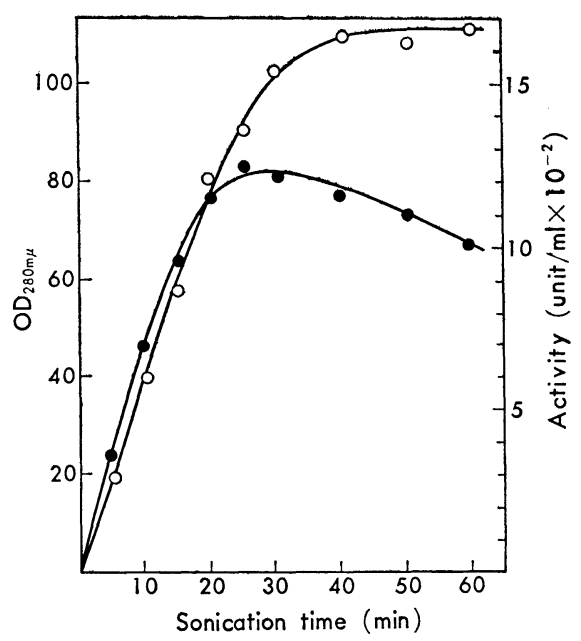

Fig. 1. Stability of the enzyme during the course of sonication.

Sonication $(9-10 \mathrm{kc})$ of washed cells $(1.2 \mathrm{~g}$ on dry basis) was carried out in $20 \mathrm{ml}$ of $0.01 \mathrm{M}$ phosphate buffer ( $\mathrm{pH} 7.0$ ) containing $20 \mu$ moles of cysteine. The sonicate was pipetted out at the indicated period and was centrifuged to remove the intact cells and debris. The enzymatic activity and optical density at $280 \mathrm{~m} \mu$ of the supernatant were measured. Assay conditions for the activity were described in Methods.

- - activity, - $\mathrm{O}-\mathrm{OD}_{280}$.

Table 1. Intracellular activity of 2-keto-6-phosphogluconate decarboxylase.

\begin{tabular}{c|c}
\hline & $\begin{array}{c}\text { Activity } \\
(\mu \mathrm{moles} / \mathrm{mg} \text { of dry cells } / \mathrm{hr})\end{array}$ \\
\hline $\begin{array}{c}\text { Assay condition } \\
\text { pH } 5.0 \\
\text { 2K-6PGA } 5 \times 10^{-3} \mathrm{M} \\
\text { Temperature } 30^{\circ}\end{array}$ & 23.5 \\
\hline Intracellular condition & 7.2 \\
pH 5.9 & \\
$2 \mathrm{~K}-6$ PGA $3.5 \times 10^{-3} \mathrm{M}$ & \\
Mg & \\
Temperature $30^{2+}$ & \\
\hline
\end{tabular}

Thus the corrected activity of $2 \mathrm{~K}-6 \mathrm{PGA}$ decarboxylase in the sonicate was determined to be $23.5 \mu$ moles $/ \mathrm{mg}$ of dry cells/hr under the standard assay conditions listed in the upper part of Table 1. It is, however, highly prob- 
able that the intracellular activity of the enzyme differs considerably from the total activity estimated under the artificial conditions. It has been found that the intracellular conditions for glucose-metabolizing cells may be assumed as those listed in the lower part of Table 1 (1), and the basic properties of the purified decarboxylase were also reported in a previous paper (11).

From these data and total activity of the decarboxylase, intracellular activity of the enzyme was calculated to be $7.2 \mu \mathrm{moles} / \mathrm{mg}$ of dry cells/hr as shown in Table 1.

The value calculated for the intracellular activity of this enzyme shows fairly good agreement with that for heterolactic fermenting activity of the glucose-metabolizing washed cells $(6.1 \mu \mathrm{moles} / \mathrm{mg}$ of dry cells $/ \mathrm{hr})$, indicating the significant participation of this decarboxylase in the metabolic pathway of heterolactic fermentation in Leuconostoc mesenteroides B07.

\section{DISCUSSION}

It has been demonstrated in several organisms that, in hexose monophosphate pathway, $6 \mathrm{PGA}$ is converted into ribulose 5 -phosphate and $\mathrm{CO}_{2}$ by the action of 6PGA dehydrogenase (decarboxylating) [EC 1.1.1.44] (16-22). Recently, however, we found that activities of 6PGA dehydrogenase (not decarboxylating) [EC 1.1.1.43] and 2K-6PGA decarboxylase were present in the crude cell-free extract of Leuconostoc mesenteroides B07, whereas activity of 6PGA dehydrogenase (decarboxylating) was absent $(10,11)$. From these results, it was estimated that oxidative decarboxylation of 6PGA may be due to the two enzymes in this strain. This estimation was, however, based on the fact that activities of these enzymes were qualitatively found in the cells under artificial conditions, and it should be noted that intracellular conditions, where these enzymes are functioning in living cells, are expected to be different from the in vitro experimental conditions. When these enzymes are quantitatively responsible for the oxidative decarboxylation of 6PGA in the fermenting cells, the intracellular activities of these enzymes should theoretically coincide with the rate of overall fermentation.

As described in the result, intracellular activity calculated for $2 \mathrm{~K}-6 \mathrm{PGA}$ decarboxylase was found to de approximately equal to that of fermentation in glucose-metabolizing cells, indicating a significant responsibility of this enzyme for metabolic pathway of the fermentation. Using 6PGA dehydrogenase (not decarboxylating) of this strain, the same result was reported in a previous paper (13). It was concluded from these results that oxidative decarboxylation of 6PGA depends quantitatively on the two enzymes present in the organism.

The authors wish to thank Dr. S. Fukui and Dr. S. Mizushima of this laboratory for many helpful suggestions. They are indebted to Dr. S. Tatsuoka, Dr. R. Takeda, and Dr. Y. Ishida, Research Laboratory of Takeda Chemical Industries, Ltd., for their advices and encouragement during this work. 


\section{REFERENCES}

1) I. TAKebe and K. Kitahara, J. Gen. Appl. Microbiol., 10, 359 (1964).

2) I. Takebe, T. Shirakawa and K. Kitahara, Abstracts of Papers, 14th Kôso Kagaku Symposium, Tokyo, p. 192 (1962).

3) I. Takebe, T. Shirakawa and K. Kitahara, Abstracts of Papers, 15th Kôso Kagaku Symposium, Osaka (1963), p. 162.

4) S. Mizushima, Y. Machida and K. Kitahara, J. Bacteriol., 86, 1296 (1963).

5) S. Mizushima and K. Kitahara. J. Bacteriol., 87, 1429 (1964).

6) S. Mizushima, T. HiYama and K. Kitahara, J. Gen. Appl. Microbiol., 10, $33^{7}(1964)$.

7) S. Mizushima and K. Kitahara, Agr. Biol. Chem. (Tokyo), 28, 339 (1964).

8) S. Mizushima and K. Kitahara, Agr. Biol. Chem. (Tokyo), 28, 344 (1964).

9) Y. Machida, S. Mizushima and K. Kitahara, J. Gen. Appl. Microbiol., 9, 433:(1963).

10) S. Yashima and K. Kitahara, J. Gen. Appl. Microbiol., 14, 359 (1968).

11) S. Yashima and K. Kitahara, J. Gen. Appl. Microbiol., 15, 169 (1969).

12) S. Yashima and K. Kitahara, J. Gen. Appl. Microbiol., 15, 289 (1969).

13) S. Yashima and K. Kitahara, J. Gen. Appl. Microbiol., 15, 413 (1969).

14) E.W. Frampton and W.A. Wood, J. Biol. Chem., 236, 2578 (1961).

15) S.B. Barker and W.H. Summerson, J. Biol. Chem., 138, 535 (1941).

16) S. Pontremoli, A. DeFlora, E. Grazi, G. Mangiarotti, A. Bonsignore, and B.L. Horecker, J. Biol. Chem., 236, 2975 (1961).

17) B.L. Horecker and P.Z. Smyrniotis. J. Biol. Chem., 193, 371 (1951).

18) B.L. Horecker, P.Z. Smyrniotis and J.E. Seegmiller, J. Biol. Chem. " 193, 383 (1951).

19) R.D. DeMoss and M. GiBBs, J. Bacteriol., 70, 730 (1955).

20) R.D. DeMoss and M.E. Heppel, J. Bacteriol., 70, 104 (1955).

21) R.D. DeMoss, Bacteriol. Proc., p. 109 (1954).

22) S.S. Cohen, In 'Phosphorous Metabolism, Vol. I, ed. by W.D. McElroy and 'B. GLass, Johns Hopkins Press, Inc., Baltimore (1951), p. 148. 